\title{
Citra Perempuan Dan Heroisme Dalam Cerpen Mademoiselle Fifi Karya Guy De Maupassant
}

\author{
Ratna $^{1}$, Zuriyati $^{1}$, Saifur Rohman ${ }^{1}$ \\ ${ }^{1}$ Program studi Ilmu Pendidikan Bahasa, Pasca Sarjana, Universitas Negeri Jakarta, \\ Jl. Rawamangun Muka, Jakarta Timur 13220 \\ Penulis untuk Korespondensi/E-mail: ratna@unj.ac.id
}

\begin{abstract}
Abstrak - Penelitian ini bertujuan untuk mendeskripsikan citra perempuan dan nilai heroisme yang direfleksikan di dalam cerpen Mademoiselle Fifi karya Guy de Maupassant, seorang penulis realis Perancis dari abad XIX.Metode yang digunakan dalam penelitian ini adalah deskriptif kualitatif dengan pendekatan kritik sastra feminis dan sosiologi sastra. Data berupa kata, frasa, dan kalimat yang berkaitan dengan citra perempuan dan nilai heroisme dalam objek yang dikaji, dikumpulkan dengan teknik studi pustaka. Data kemudian diklasifikasi, diinterpretasi, dan dianalisis dengan landasan teoretis yang relevan. Hasil penelitian menunjukkan bahwa perempuan dicitrakan sebagai sosok yang pemberani, cerdas, dan agresif. Namun, di level sosial dan pendidikan, perempuan masih dianggap berada di bawah kuasa laki-laki. Nilai heroisme lewat tokoh Rachel dapat dilihat saat ia berani melawan Mademoiselle Fifi, saat ia setia membela kehormatan tentara Prancis, dan saat ia berani mengambil risiko untuk membunuh Mademoiselle Fifi.
\end{abstract}

Abstract - This study aims to describe the image of women and heroism which are reflected in Mademoiselle Fifi short story written by Guy de Maupassant, a French writer in 19th century. The methodology used in this study is qualitative descriptive with feminist criticism theory and literary sociology approaches. The data of this study are the words, phrases, and sentences related to the image of women and heroism in the research object, examined through the literature review technic. The data will later be classified, interpreted, and analyzed using relevant theories. The result of the study shows that women are depicted as brave, clever, and aggressive. However, in the social and educational level, women are still thought of under men's control. Heroism values in Rachel can be seen at the moment when she is brave to fight against Mademoiselle Fifi, when she defends the honor of French soldiers and when she is brave enough to take a risk in murdering Mademoiselle Fifi.

Keywords - The image of women, Heroism, Guy de Maupassant, Mademoiselle Fifi.

\section{PENDAHULUAN}

$\mathrm{P}$ enelitian dengan cerita pendek karya Guy de Maupassant sebagai sumber data sudah beberapa kali dilakukan oleh para peneliti sebelumnya. Penelitian terdahulu di antaranya telah membahas beberapa topik yang berfokus pada budaya material, keberanian perempuan, dan ketangguhan perempuan menghadapi budaya patriarki yang melekat pada masa perang, bahkan sampai saat ini.

Melihat beberapa penelitian yang sudah dilaksanakan sebelumnya, peneliti menemukan bahwa penelitian yang berfokus pada citra tokoh perempuan dan nilai heroisme yang dihubungkan dengan latar tempat saat cerita pendek dibuat, utamanya karya Guy de Maupassant yang berjudul Mademoiselle Fifi belum dibahas secara mendalam. Maka, penelitian ini dibuat untuk meneruskan penelitian sebelumnya yang membahas tentang citra tokoh perempuan di karya-karya cerita pendek Guy de Maupassant.

Sebagai penulis yang hidup pada periode perang Prancis-Jerman atau biasa disebut dengan FrancoPrussian War dan pernah mengabdikan dirinya di militer, latar tempat maupun kejadian di dalam karya - karya Guy de Maupassant banyak dipengaruhi oleh situasi perang pada zaman itu, yang menggambarkan tragedi dan penderitaan yang dialami oleh kaum sipil yang diceritakan dengan jelas di dalam karya- 
karyanya. Hal itu dapat dilihat dari situasi yang diceritakan dalam karyanya yang berjudul Mademoiselle Fifi.

Dalam cerita pendek Mademoiselle Fifi, peneliti berfokus pada tokoh perempuan yang digambarkan hanya sebagai pelacur yang menjadi objek hiburan laki-laki setelah perang berakhir. Dalam cerita ini, dapat dilihat bahwa status sosial perempuan berada di bawah laki-laki. Mademoiselle Fifi bercerita tentang anggota tentara Prussia yang telah berhasil memenangkan perang dan sedang berbincang sebelum makan siang. Perbincangan mereka tidak jauh dari pembahasan tentang hiburan dan perempuan.

Total ada lima perempuan 'hiburan' yang datang untuk menghibur para perwira. 'Pembagian' perempuan-perempuan ini pun dinilai dari pangkat yang dimiliki oleh para perwira. Semakin tinggi pangkat yang dimiliki, semakin molek perempuan yang akan menemani. Dari pembagian tersebut, citra tokoh perempuan dan nilai heroisme mulai berusaha dibangun oleh Guy de Maupassant.

Problematika yang diteliti dalam artikel ini adalah citra perempuan dan nilai heroisme yang direfleksikan dalam cerpen Mademoiselle Fifi. Dalam cerpen Mademoiselle Fifi, tokoh perempuan bernama Rachel menjadi center perhatian utama di antara perempuan-perempuan yang lain. Ia adalah sosok yang digambarkan memiliki sifat pemberani, pembangkang, pintar, dan memiliki jiwa nasionalisme yang tinggi. Untuk meneliti lebih lanjut tentang citra perempuan dan nilai heroisme yang terkandung di dalam cerpen Mademoiselle Fifi, peneliti ingin menganalisis sejauh mana Guy de Maupassant, yang merupakan seorang penulis lakilaki merefleksikan konsepsi feminisme di dalam karyanya melalui kritik sastra feminis.

Kritik sastra feminis fokus pada ilmu sastra yang menekankan penelitian melalui perspektif feminis. Kata feminis, secara etimologis, berasal dari kata Femme (woman), yang memiliki arti perempuan (tunggal), adapun fokus utamanya adalah untuk mendapatkan hak-hak perempuan (jamak) pada kelas sosial [1]. Gerakan feminisme sendiri mulai bermunculan di awal abad 19. Mulanya, gerakan feminisme didorong oleh ketidakadilan hak-hak yang dimiliki oleh perempuan atas dirinya sendiri. Pada tahun 1863, perempuan dianggap akan kehilangan 'kemerdekaannya' saat memutuskan untukmenikah.
Sampai saat ini, feminisme telah terbagi ke dalam empat gelombang; Gelombang feminis pertama, yang dikenal dengan Suffrage, dimana perempuan meminta hak suara (vote) dan hak keterlibatan dalam demokrasi; gelombang kedua, yang dikenal dengan equal pay, diawali dengan gerakan di Amerika, lalu meluas ke Eropa dan akhirnya Asia, dimana perempuan menuntut hak yang sama dalam hal seksualitas, karir, selisih gaji yang sama dengan kaum lawan jenisnya, dan hak reproduksi lainnya; gelombang ketiga, lebih jauh perempuan meminta haknya atas kesetaraan gender di tengah budaya patriarki yang sangat merugikan pihak perempuan, seperti perlindungan korban kekerasan seksual, labelisasi inferioritas atas budaya patriarki, dan rape culture yang sangat merugikan kaum perempuan; dan gelombang keempat, yang merupakan pengembangan dari gelombang ketiga, berfokus pada sexual harassment dan body authority.

Lebih jauh, budaya patriarki inilah yang kemudian membuat perempuan mendapatkan diskriminasi di berbagai sektor. Diskriminasi itu dapat dilihat dalam sektor ekonomi, di mana perempuan dimarginalisasi, adanya subordinasi perempuan dalam sektor politik, lalu pembentukan stereotipe dan labelisasi negatif atas perempuan, ketidakadilan distribusi beban kerja, dan minimnya sosialisasi ideologi nilai peran gender (Fakih dalam [2])

Dalam perspektif feminis, citra perempuan yang digambarkan oleh penulis laki-laki seringkali ditentukan oleh pendekatan budaya patriarki yang sebenarnya tidak mencerminkan keadaan yang dialami oleh perempuan dan cenderung menimbulkan penilaian yang tidak sesuai [3]. Karya sastra yang didominasi oleh penulis laki-laki umumnya mengandung penggambaran stereotipestereotipe yang tidak tepat atas perempuan (Kolodny dalam [4]). Tokoh perempuan dianggap sebagai inferior, sedangkan laki-laki adalah superior.

Superioritas atau dominasi laki-laki menimbulkan citra bahwa perempuan merupakan pelayan lakilaki, seorang istri yang penurut, dan ibu yang mencurahkan seluruh perhatiannya untuk anakanaknya, seperti dapat dilihat pada tokoh Nora dalam cerita $A$ Doll's House milik Henry Ibsen. Adapun dalam cerita Mademeoiselle Fifi, lewat tokoh para pelacur perempuan dan bagaimana para perwira memperlakukan perempuan, dapat dilihat bahwa Guy de Maupassant menggambarkan citra perempuan sebagai sebuah 'properti' yang dapat dibeli, dimiliki, dan diperlakukan sewenang-wenang oleh laki-laki. 
Nilai heroisme kerap berkaitan dengan kepahlawanan. Nilai kepahlawanan itu sendiri ada tiga, yaitu nilai kesetiaan, nilai rela berkorban, dan nilai keberanian [5]. Keberanian dalam membela keadilan dan kebenaran merupakan nilai dan sifat yang terkandung dalam heroisme. Heroisme identik dengan aktivitas kemiliteran [6]. Namun, pada implikasinya, heroisme tidak hanya terbatas pada aktivitas militer, melainkan juga telah melekat pada seluruh elemen masyarakat [7]. Di dalam cerita Mademoiselle Fifi, implikasi nilai dan pemikiran herois dapat dilihat dalam tindakan -tindakan seperti saat tokoh Rachel membela para tentara Prancis yang diremehkan oleh tentara Prussia.

Penelitian terdahulu yang menggunakan cerpen Guy de Maupassant adalah penelitian oleh Khairunnisa Putri yang berjudul An Analysis of Woman's Bravery in Guy de Maupassant's Selected Short Stories (2018). Penelitian Putri fokus mengkaji keberanian perempuan-perempuan terhadap para tentara dalam cerita pendek Guy de Maupassant dalam 'melacurkan' diri mereka. Penelitian ini meneruskan penelitian dari Putri, namun hanya berfokus pada Rachel yang digambarkan pemberani dan memiliki nilai heroisme dalam membela negaranya.

Lebih lanjut, penelitian oleh Mawar Fajar Sari yang berjudul Citra Para Tokoh Wanita dalam Cerpen Clochette, Boule de Suif, Histoire d'Une Fille de Ferme dan Mademoiselle Fifi Karya Guy de Maupassant: Tinjauan dari Perspektif Feminisme Julia Kristeva (2013). Penelitian Sari fokus mengkaji citra para tokoh perempuan melalui paradigm feminisme dari Julia Kristeva. Tokoh perempuan dalam penelitian Sari masih digambarkan seolah-olah tidak terhormat dan hanya mencoba untuk bersabar dalam menghadapi diskriminasi dan penindasan. Berbeda dengan penelitian Sari, dalam penelitian ini, tokoh perempuan memiliki keberanian untuk membangkang.

Kajian tentang citra perempuan telah dilakukan di antaranya oleh Choerul Anam pada penelitian yang berjudul Citra Perempuan dalam Novel Cerita tentang Rani Karya Herry Santoso; Tinjauan Kritik Sastra Feminis [8]. Santoso fokus mengkaji citra tokoh Rani sebagai perempuan yang kuat dan tangguh. Penelitian ini meneruskan penelitian Anam dalam mencari penggambaran lebih lanjut tentang citra tokoh perempuan. Lalu, kajian oleh Budi Mulyadi yang berjudul Menyibak Citra Perempuan dalam Cerpen "Maria" (Sebuah Kajian Sastra
Feminis) [9]. Mulyadi mengkaji citra tokoh Maria sebagai seorang perempuan yang mandiri dan tidak bergantung pada laki- laki. Penelitian ini juga meneruskan penelitian sebelumnya tentang bagaimana tokoh perempuan berusaha mandiri lewat melacurkan diri mereka, meskipun masih harus berkutat dalam belenggu laki-laki.

Selanjutnya, ada kajian oleh Rini dkk.yang berjudul Citra Perempuan pada Novel Hati Sinden Karya Rahyuningsih (Kajian Feminisme Marxis) [10]. Penelitian Rini dkk. fokus mengkaji perempuan dalam usahanya melepas belenggu patriarki. Lebih jauh, kajian oleh Ai Rohmawati yang berjudul Citra Perempuan dalam Naskah Ratu Dewi Maleka: Kajian Feminis Ideologis [11]. Rohmawati mengkaji citra dan kedudukan tokoh perempuan dalam lingkungan keluarga, masyarakat, dan negara. Penelitian ini meneruskan kajian Rini tentang bagaimana perempuan berusaha menumbuhkan citra yang dapat membela negara dan dirinya sendiri.

Nilai heroisme juga telah beberapa kali ditelaah seperti yang dilakukan oleh Badio dkk. pada penelitian yang berjudul Nilai Perjuangan dalam Novel Arus Balik Karya Pramoedya Ananta Toer [12]. Badio dkk. fokus mengkaji perjuangan tokoh yang mencakup nilai heroisme, nasionalisme, pantang menyerah, kekeluargaan, dan tanpa pamrih. Penelitian ini meneruskan kajian Badio tentang cakupan nilai heroisme yang dapat ditemukan dalam cerita.

Selanjutnya, penelitian oleh Rantan Sari dkk. yang fokus mengkaji nilai-nilai kepahlawanan yang mencakup tiga hal, yaitu nilai keberanian tokoh utama, nilai kesetiaan tokoh utama, dan nilai rela berkorban. Hasil penelitian itu dapat dilihat pada jurnal yang berjudul Nilai-nilai Kepahlawanan dalam Novel Aku Bukan Jamilah Karya Robert Juki Ardi (2016). Penelitian ini juga mencari cakupan lebih luas tentang bagaimana nilai heroisme tokoh perempuan dalam membela negaranya.

Dengan berdasarkan seluruh paparan tersebut, maka tujuan penelitian ini adalah untuk mengetahui citra perempuan dan nilai heroisme perempuan yang digambarkan oleh Guy de Maupassant di masa perang menggunakan kritik sastra feminis dan sosiologi sastra.

\section{METODE}

Objek material penelitian yang digunakan oleh peneliti adalah sebuah buku kumpulan cerpen karya 
Guy de Maupassant berjudul Mademoiselle Fifi. Buku ini diterbitkan pada tahun 2004.Terdiri dari 25 cerpen karya Guy de Maupassant. Namun, yang akan menjadi objek penelitian hanyalah satu cerita pendek berjudul Mademoiselle Fifi, yang terletak pada bagian akhir buku. Adapun objek formal yang akan diteliti adalah citra perempuan dan nilai heroisme perempuan di masa perang.

Metode yang digunakan adalah metode deskriptif dengan bentuk penelitian kualitatif. Penggunaan metode deskriptif bertujuan untuk menganalisis sumber data yang berbentuk kata, frasa, dan kalimat. Mengutip dari definisi Moleong yang menyatakan bahwa data yang dikumpulkan dalam bentuk katakata, gambar, dan bukan angka adalah jenis metode deskriptif [13]. Lebih jauh, sumber data akan dianalisis dengan pendekatan kritik sastra feminis dan sosiologi sastra.

Kritik sastra feminis adalah salah satu dari berbagai disiplin ilmu sastra yang menekankan penelitian dengan perspektif feminis [14]. Kritik sastra feminis digunakan karena tokoh utama yang akan dianalisis adalah seorang perempuan yang bernama Rachel. Selain itu, penerapan kritik sastra feminis dalam penelitian ini berfokus pada citra perempuan yang digunakan sebagai simbol untuk menghadapi patriarki.

Sedangkan, sosiologi sastra adalah pendekatan terhadap karya sastra yang memperhatikan segi-segi kemasyarakatan [15].. Terlepas dari tokoh perempuan sebagai objek penelitian, keadaan sosial saat cerita ini dibuat, serta latar tempat dan waktu juga mendukung bagaimana citra perempuan dan nilai heroisme dapat terbentuk di suatu kawasan sosial. Untuk itu, peneliti juga akan sedikit mengulas unsur intrinsik sebagai gambaran jelas yang dapat mendukung sumber data.

Teknik pengumpulan data yang digunakan untuk menganalisis cerita pendek milik Guy de Maupassant adalah teknik studi pustaka. Teknik ini memberi kemudahan kepada peneliti untuk mengumpulkan sumber data lain yang berkaitan dengan situasi sosial objek yang diteliti. Hal ini sesuai dengan pendapat Sugiyono yang mengafirmasi bahwa studi kepustakaan berkaitan dengan kajian teoritis dan referensi terdahulu yang memiliki relevansi dengan nilai, budaya, dan norma yang berkembang pada situasi sosial yang diteliti [16]. Data-data yang memiliki relevansi itu dapat berupa buku, jurnal, dan artikel.
Teknik analisis data yang digunakan untuk penelitian ini diawali dengan mengklasifikasi data data dalam bentuk kata, frasa, dan kalimat yang ada pada cerita pendek. Data-data yang diklasifikasi tersebut sudah melalui tahap reduksi, sehingga hanya data yang berkaitan dengan citra perempuan dan nilai heroisme saja yang tersisa. Selanjutnya, data-data tersebut akan diinterpretasi dan dianalisis dengan teori yang relevan menggunakan pendekatan kritik sastra feminis dan sosiologi sastra. Langkah terakhir yang akan dilakukan oleh peneliti adalah menarik kesimpulan tentang bagaimana refleksi citra perempuan dan nilai heroisme perempuan di masa perang dalam cerpen Mademoiselle Fifi karya Guy de Maupassant.

Landasan teoretis yang digunakan dalam penelitian ini, adalah tentang citra perempuan sebagai gambaran yang diimplementasikan melalui katakata dan dibangkitkan melalui kata-kata [17]. Citra perempuan itu dapat dianalisis melalui sudut pandang kritik sastra feminis-sosialis. Kritik sastra ini menggabungkan antara dua sudut pandang yang saling berkaitan, yaitu feminisme dan sosiologi. Kritik sastra feminis-sosialis menilai karya sastra melalui tokoh- tokoh perempuan dalam hubungannya di dalam kelas-kelas sosial kemasyarakatan [4]. Kelas-kelas sosial itu dapat dilihat dari level sosial, ekonomi, dan pendidikan [10]. Sedangkan, nilai heroisme dianalisis berdasarkan tiga nilai kepahlawanan yang dikemukakan oleh Sari, yaitu (1) nilai keberanian, yang dapat dinilai dari sikap bertahan atas hal yang dipercayai, meskipun mendapat tekanan, (2) nilai kesetiaan, yang dapat dinilai dari keteguhan seseorang terhadap hal yang tidak akan dilanggar, dan (3) nilai rela berkorban, yang dapat dilihat dari kesediaan untuk melakukan hal yang bisa merugikan dirinya sendiri demi orang tua atau orang-orang di sekitarnya [5].

\section{HASIL DAN PEMBAHASAN}

\section{Narasi tentang Kritik Sosial dan Subordinasi Perempuan}

Cerita pendek Mademoiselle Fifi karya Guy de Maupassant berlatar di sebuah kastil bernama 'Kastil Uville' di Prancis pada saat perang Prancis-Prusia atau biasa disebut Prancis-Jerman yang berlangsung pada tahun 1870-1871. Di dalam kastil itu, ada lima tokoh perwira laki-laki yang diceritakan menempati kastil, salah satu di antaranya adalah Mademoiselle Fifi, yang kemudian menjadi sumber konflik di dalamcerita. 
Pada perang ini, Prancis berhasil ditaklukkan oleh Jerman. Beberapa perwira Jerman yang menempati kastil itu merasakan keadaan yang suram, sepi, dan mencekam setelah perang usai. Mereka membutuhkan sebuah pesta di mana salah satu 'hiburan' dapat dicari dari sosok perempuan.Seperti pada kutipan berikut.

Ia berpikir beberapa detik, lalu menjawab: "Kita harus menyelenggarakan pesta atas seizin Komandan.”

Atasannya menurunkan pipanya: "Pesta apa, Kapten?"

Baron itu menghampiri: "Biar sayalah yang mengurusnya, Pak Komandan. Akan saya suruh si patuh pergi ke Rouen untuk menjemput perempuan- perempuan [...] kita akan dapat bersenang-senang malam ini." (hal. 339)

Kata 'bersenang-senang' mengacu pada kegiatan yang akan mereka lakukan setelah hadirnya para perempuan penghibur. 'Hiburan' ini menunjukkan adanya subordinasi perempuan pada masa perang. Posisi perempuan dianggap berada satu tingkat di bawah laki-laki. Tingkatan ini menunjukkan kelas sosial yang menjadi perhatian utama peneliti. Kelas sosial itu dapat diteliti melalui beberapa perbandingan, merujuk pada teori dari [10] bahwa kelas sosial dapat dilihat dari segi sosial, ekonomi, dan pendidikan.

Perbandingan pertama dilihat dari status sosial. Pada cerita ini, laki-laki digambarkan dengan sosok perwira yang membela negara dan memiliki nilai juang. Sedangkan, citra perempuan hanya dianggap sebagai 'properti' atau benda milik pribadi (dengan lakon sebagai pelacur) yang harga dirinya dapat dibeli untuk kesenangan laki-laki. Dimulai dari saat Baron meminta izin kepada Komandan untuk menjemput para perempuan di Rouen dan saat Sang Komandan, yang memiliki status sosial tertinggi, mendapat kekuasaan penuh untuk memilih dan memberikan penilaian pada perempuan-perempuan yang ia kehendaki. Adegan itu dapat dilihat pada kutipan berikut.

Sang Kapten, dengan muka berseri-seri, memilih perempuan-perempuan itu seperti benda milik pribadi [...] Setelah kemudian mencium Blondine, yang kedua sebagai tanda memiliki, ia memberikan Amanda yang montok kepada Letnan Otto, Eva yang dijuluki Tomat kepada Fritz dan yang paling kecil, Rachel, kepada perwira termuda Marquis Wilhelm
d'Eyrik yang paling langsing. (hal. 349)

Maka marquis yang pendek itu menaruh di atas kepala perempuan Yahudi itu gelas champagne yang sudah diisi lagi: "Milik kita juga," serunya, "semua perempuan Prancis!" (hal. 356)

Adegan itu menunjukkan bahwa laki-laki berkuasa penuh atas perempuan, selama mereka memiliki uang. Ini berkaitan dengan perbandingan kedua, dilihat dari segi ekonomi, sudah pasti para perwira lebih tinggi derajat dan martabatnya dibandingkan dengan para pelacur yang berada di sana. Dengan kemampuan laki- laki membayar perempuan untuk memenuhi kebutuhan hasrat biologis mereka, hal ini membuktikan bahwa lagi-lagi perempuan berada satu tingkat di bawah laki-laki. Dalam cerita ini, saat para pelacur sudah 'dibagi' oleh Komandan, para perwira memiliki kuasa penuh untuk melakukan apa saja kepada 'properti' mereka. Mereka bebas untuk mencumbu, merusak, bahkan melukai para pelacur yang telah mereka bayar.

Pada saat masa perang, bukan sebuah hal yang tabu jika tentara bebas memilih perempuan mana saja yang ia inginkan tanpa perlu mengeluarkan uang. Namun, di sisi lain perbandingan ini juga menunjukkan bahwa perempuan memiliki citra yang pintar dan pemberani. Keberanian dan kecerdasan perempuan dapat dinilai saat mereka mempolitisasi dan menguasai tubuh mereka sendiri dengan cara memasang harga untuk melayani, walaupun terkadang mereka harus tersakiti atas tindak dan perlakuan si 'penyewa'. Tak jarang, para perempuan digambarkan memiliki citra yang agresif. Saat ingat pekerjaannya sebagai pemuas hasrat para perwira, mereka tak malu untuk mencumbu lebih dulu. Lebih jauh, para perempuan menganggap bahwa apa yang mereka kerjakan semata-mata hanyalah tuntutan profesi, mereka tidak terlalu ambil pusing perihal kenyataan bahwa pelanggan yang akan mereka layani adalah musuh negara. Seperti pada kutipan berikut.

Sekali lagi perempuan itu menatapnya luruslurus, dan sambil mencuci lukanya ia berbisik: "Ini harus dibayar." Perwira Jerman itu tertawa ngakak. "Aku akan membayarnya," katanya. (hal. 353)

Belum selesai ia berbicara, perwira itu menamparnya sekuat tenaga. (hal. 357).

Perbandingan ketiga dapat dilihat dari segi pendidikan. Di dalam cerita ini, karena Jerman 
berhasil menaklukkan Prancis, Jerman dianggap memiliki kuasa atas suatu negara. Lebih jauh, atas dasar itu pula para tokoh perwira laki-laki dianggap memiliki pendidikan yang lebih tinggi karena sekolah perwira merupakan momok yang dapat disegani pada masa perang. Sedangkan citra perempuan (lewat lakon pelacur), dianggap remeh dan tidak memiliki pengetahuan yang setara dengan para perwira. Hal itu dapat dilihat pada tanggapan para perempuan saat menerima basa - basi dari para perwira dengan dialek wilayah Sungai Rhin. Para perempuan itu tidak mengerti apa yang dibicarakan oleh para perwira.

Lebih jauh, saat diperlakukan sewenang-wenang, perempuan-perempuan itu pun hanya memunduk tak berani membalas ketika diremehkan, kecuali tokoh perempuan bernama Rachel. Beberapa kali perwira meremehkan perempuan Prancis dan negara Prancis melalui kata-kata sarkastis dan tidakan mereka. Seperti pada kutipan berikut.

Perwira itu duduk dengan santai, dan berusaha berbicara dengan aksen Paris: "Wah, wah, ia hebat sekali, hebat. Jadi apa yang akan kau kerjakan di sini, anak manis?” (hal.356)

Penyebutan kata 'hebat' tentu bukan dalam arti sebenarnya. Melihat dari konteks situasi, Mademoiselle Fifi mengatakan hal itu untuk menyindir tokoh Rachel yang menentang ucapannya bahwa perempuan-perempuan Prancis adalah milik mereka, perwira Jerman. Sedangkan pada kenyataannya, kalimat 'apa yang akan kau kerjakan di sini' bertujuan untuk mengejek para perempuan Prancis yang sedang 'bekerja' dan berada di bawah kendali mereka.

\section{Nilai Heroisme Perempuan di Masa Perang}

Nilai heroisme perempuan di masa perang pada cerita pendek Mademoiselle Fifi dapat dilihat melalui tokoh bernama Rachel. Sebagaimana disebutkan di atas, di antara lima tokoh perempuan, tokoh Rachel paling mencolok karena citranya yang pintar dan berani, sesuai dengan salah satu dari tiga nilai heroisme menurut Sari. Selain itu, untuk melengkapinya, Rachel juga memiliki dua sifat heroisme lain, seperti kesetiaan dan rela berkorban.

Secara umum, semua perempuan yang ada di dalam cerita pendek ini memiliki nilai keberanian karena mereka berani melakukan tindak prostitusi untuk melayani musuh negara. Namun, untuk lebih rinci, peneliti akan fokus membahas tokoh Rachel sebagai tokoh perempuan utama yang memiliki nilai-nilai kepahlawanan atau heroisme.

Rachel merupakan perempuan keturunan Yahudi yang tinggal di Prancis dan bekerja sebagai seorang pelacur. Di antara teman kerjanya yang lain, Rachel merupakan yang termuda. Oleh karena itu, ia diberikan kepada Mademoiselle Fifi, yang juga perwira paling langsing di antara perwira lainnya. Sifat Mademoiselle Fifi yang dideskripsikan senang mencemooh orang lain menimbulkan konflik saat dihadapkan dengan Rachel, perempuan yang paling berani melawan perilaku para perwira yang kelewatbatas.

Ada beberapa sikap yang menunjukkan bahwa Rachel adalah seorang yang memiliki nilai heroisme, dapat dilihat saat Mademoiselle Fifi menyulutkan asap tembakau ke dalam mulutnya. Menanggapi hal itu, Rachel dengan berani menatap marah kepada Mademoiselle Fifi. Lalu, saat adegan Mademoiselle Fifi melukai bibirnya akibat percumbuan panas, dengan berani Rachel meminta bayaran tambahan sebagai ganti rugi. Tidak hanya sampai di situ, Rachel kembali marah dan berteriak ke arah wajah Mademoiselle Fifi saat lelaki itu mencemooh para tentara Prancis. Puncak keberanian Rachel adalah saat ia menancapkan pisau di leher Mademoiselle Fifi sebagai bentuk perlawanan atas tamparan dan hinaan yang ia terima. Adegan itu dapat dilihat pada kutipanberikut.

Belum sempat ia berbicara, perwira itu menamparnya sekuat tenaga. Tetapi ketika perwira itu mengangkat tangan lagi, dengan garang karena marah, Rachel menyambar pisau perak cuci mulut yang ada di meja, dan dengan sangat tiba-tiba, sehingga hampir tak terlihat, ia menancapkannya langsung di leher laki-laki itu, tepat di celah sebelum dada.

Tindakan Rachel dinilai sangat berani karena pada akhirnya, ia berhasil membunuh perwira tersebut dan kabur tanpa pernah tertangkap. Selain nilai keberanian yang ia tunjukkan, ia juga sangat setia membela Prancis yang dicemooh oleh Mademoiselle Fifi. Berkali-kali perwira itu melemparkan kalimatkalimat yang menyinggung bagaimana hebatnya Jerman dalam menaklukkan Prancis yang dianggap tidak memiliki kekuatan. Rachel dengan setia membela kehormatan para tentara Prancis dengan mengatakan bahwa Mademoiselle Fifi tidak akan berani mencemooh para tentara Prancis jika mereka ada di hadapannya langsung. Tak cukup sampai di situ, Rachel bahkan juga membela perempuanperempuan Prancis yang dianggap hanya sebagai 
pemuas nafsu para tentara Jerman. Rachel mengatakan bahwa tentara Jerman tidak akan pernah mendapatkan perempuan - perempuan Prancis. Namun, hal ini berbanding terbalik dengan apa yang sedang mereka lakukan di sana; menjual diri kepada tentara Jerman. Seperti dapat dilihat pada kutipanberikut.

“....Kalian tidak akan pernah 'dapat perempuan Prancis [...] Aku! Aku! Aku bukan perempuan, aku ini hanya pelacur, tahu! Hanya pelacur yang boleh dimiliki orang Prusia...!" (hal.356-357)

Di tengah perdebatan panas antara Rachel dan Mademoiselle Fifi, Rachel sampai berani mengatakan bahwa perempuan Prancis berbeda dengan pelacur Prancis. Ia memosisikan dirinya sebagai pelacur, bukan perempuan Prancis. Jadi, wajar saja jika para tentara Jerman bisa mendapatkannya.

Nilai heroisme lain yang terdapat dalam diri Rachel adalah saat dia rela mengorbankan keselamatannya sendiri demi menjaga nama baik Prancis. Rachel, tanpa banyak berpikir, menghunuskan sebuah pisau ke leher Mademoiselle Fifi. Hal itu tentu sangat berbahaya bagi dirinya sendiri. Ia bisa saja diburuh dan dibunuh oleh para tentara Jerman. Namun, Rachel sudah tidak peduli. Ia terlalu marah mendengar ocehan Mademoiselle Fifi tentang Jerman danPrancis.

\section{KESIMPULAN}

Cerita pendek Mademoiselle Fifi berlatar masa perang Prancis - Prusia. Konflik yang disuguhkan oleh Guy de Maupassant membuat peneliti menemukan citra perempuan dan nilai heroisme perempuan yang digambarkan melalui tokoh- tokoh dan kejadian yang ada di dalam cerita. Citra perempuan yang digambarkan oleh Guy de Maupassant secara general adalah pemberani, karena mereka berani menentukan nasib mereka sendiri dengan memasarkan diri melalui jalur prostitusi dan melayani tentara Prusia. Namun, citra perempuan dari segi sosial masih digambarkan sebagai 'barang pribadi' milik laki-laki, yang bisa diperlakukan sesuai kehendak pemiliknya. Dari segi ekonomi, citra perempuan digambarkan sedikit unggul karena Guy de Maupassant menggambarkan citra yang pemberani, cerdas, dan sedikit agresif dalam menguasai tubuh mereka sendiri. Dari segi pendidikan, perempuan masih dicitrakan sebagai makhluk yang remeh, tetapi cukup pintar berkelit.
Untuk nilai heroisme perempuan di masa perang, tokoh Rachel cukup berpengaruh. Nilai heroisme itu dapat dilihat saat Rachel berani melawan Mademoiselle Fifi, saat Rachel dengan setianya membela tentara Prancis di depan Mademoiselle Fifi, dan saat Rachel rela berkorban mengambil risiko besar ketika ia memutuskan untuk menusuk Mademoiselle Fifi dengan sebilah pisau tepat bertengger dilehernya.

\section{REFERENSI}

[1] N. K. Ratna, Teori, Metode, dan Teknik Penelitian Sastra dari Strukturalisme hingga Postrukturalisme., Yogyakarta: Pustaka Pelajar, 2004.

[2] Kadarusman, Agama, Relasi Gender\& Feminisme, Yogyakarta: Kreasi Wacana, 2005.

[3] Qomariyah, "Citra Perempuan Kuasa dalam Prespektif Kritik Sastra Feminis Novel Perempuan Berkalung Sorban Karua Abidah El-Khalieqy," Jurnal Bahasa dan Sastra, vol. 7, no. 12, 2011.

[4] S. Djajanegara, Kritik Sastra Feminis, Sebuah Pengantar, Jakarta: Ikhrar Mandiri, 2003.

[5] Sari, "Nilai - Nilai Kepahlawanan dalam Novel Aku Bukan Jamilah Karya Robert Juki Ardi," Jurnal Pendidikan dan Pembelajaran Khatulistiwa, vol. 5, no. 2, pp. 1-12, 2016.

[6] Z. Franco and P. Zimbardo, The banality of heroism, Greater Good, 2007.

[7] W. Primasari, "Heroisme Amerika dalam film," Makna, vol. 4, no. 2, pp. 35 - 53, 2014.

[8] C. Anam, "Citra Perempuan dalam Novel Cerita Tentang Rani Karya Herry Santoso; Tinjauan Kritik Sastra Feminis," Alayasastra, vol. 15, no. 2, pp. 71-89, 2019.

[9] B. Mulyadi, "Menyibak Citra Perempuan dalam Cerpen,"Maria" (Sebuah Kajia Sastra Feminisme)," Humanika, vol. 2, no. 25, pp. 88 -95, 2018.

[10] A. M. L. Rini, Martono and S. Seli, "Citra Perempuan pada Novel Hati Sinden Karya Dwi Rahyuningsih (Kajian Feminisme Marxis)," Jurnal Pendidikan dan Pembelajaran Untan, 2014.

[11] A. Rohmawati, "Citra Perempuan dalam Naskah Ratu Dewi Maleka: Kajian Feminis Ideologis," Jurnal Manuskrip Nusantara, vol. 
4, no. 2, 2013.

[12] S. Badio, B. Nurgiyantoro and Hartono, "Nilai Perjuangan Dalam Novel Arus Balik Karya Pramoedya Ananta Toer," Indonesian Language Education and Literature (ILEAL), vol. 5, no. 1, 2019.

[1] L. J. Moleong, Metode Penelitian Kualitatif, Bandung: Remaja Rosdakarya, 2010.

[14] Sugihastuti, Kritik Sastra Feminis, Teori dan Aplikasinya, Yogyakarta: Pustaka Belajar, 2000.
[15] S. D. Damono, Sosiologi Sastra Pengantar Ringan Edisi Baru, Ciputat: Editum, 2009.

[16] Sugiyono, Metode Penelitian Kuantitatif, Bandung: PT Alfabet, 2016.

[17] A. Sofia, Aplikasi Kritik Sastra Feminisme, Yogyakarta: Citra Pustaka, 2009. 